Research Article

Agnieszka Laddach*

\title{
Sexuality and Gender Diversity in the Liberal Catholic Discourse in Poland in the Pastoral Perspective
}

https://doi.org/10.1515/opth-2020-0165

received May 10, 2021; accepted July 12, 2021

\begin{abstract}
One of the most important questions in the Roman Catholic Church is the question of sexual and gender diversity. Therefore, the article presents the results of qualitative and quantitative content analysis of the Catholic sociocultural periodical Więz (Bond) from 2007 to 2020, which is the leading forum for liberal Catholic debates in Poland. The goal was to analyze the period's narration toward current Church's instructions on sexuality and gender diversity. Five dominant postulates were identified in Więź: (1) a discussion about people with the need to revise their or the Church's narration on and experience of sex and gender; (2) a reevaluation of the significance and consequence of sexual revolution in Poland; (3) an organization of the understanding of body, sex, sexuality, and gender; (4) a promotion of the idea of encounter; and (5) a settlement of cases of sexual abuse in the Church. The article concludes that the presence of social dialogue on sexuality and gender diversity in the current pastoral approach of the Church in Poland requires a suspension of moral judgment and an openness from Church with a strong traditional, and rigid viewpoint to better understand the difficult spiritual and social situation of people who live contrary to the moral teachings of the Church or whose views go against these teachings.
\end{abstract}

Keywords: Poland, gender, sexuality, Catholicism, faith, critical discourse analysis

\section{Introduction}

The consequences of the sexual revolution in the 1960s and 1970s in the West, along with the increasing public awareness of sexual abuses in and outside the Roman Catholic Church, are two of the many points in the current public discussion on sexuality and gender diversity in Poland. The debate is present in the Church, especially regarding Karol Wojtyła's (Pope John Paul II) moral thought on experiencing body and sex as spaces for communication between spouses. ${ }^{1}$ Moreover, there is a differential press image of LGBTQ+ people in the main Catholic right-conservative weeklies representing the so-called open Church. The bipolarity of the narrative was expressed in the analyzed press titles, including a different understanding of the profane/sacrum category, religious symbols, cultural moral revolution, and a different use of mediatization metaphors toward critics of the LGBTQ+ community. ${ }^{2}$ The traditional, right-wing view is clearly articulated and supported by many bishops and priests in Poland. They officially and unofficially

1 John Paul II, Man and Woman He Created Them; Wojtyła, The Jeweler's Shop; Wojtyła, Love and Responsibility.

2 Leśniczak, "Patriotyzm, homofobia i nietoleracja," 103-20.

\footnotetext{
* Corresponding author: Agnieszka Laddach, Academia Artium Humaniorum, Nicolaus Copernicus University, Toruń, Poland, e-mail: Laddach@interia.pl
} 
(indirectly) reinforce right-wing voices in the Polish society and express their postulates through social actions such as Stop LGBT, March for Life and Family, and initiatives of the Ordo Iuris Institute for Legal Culture. Some of clergymen support the "anti-gender" debate initiated by the Catholic Church in Poland, contribute to undermining gender theories, and blame gender theorists for societal flaws. ${ }^{3}$ In this context, the liberal Catholic discourse in Poland remains weak, reduced to a minority, and only feebly articulated in the public sphere. The main space for presenting liberal voices in Poland's Catholic community is the sociocultural periodical Więź (Bond). This article aims to show the results of my analysis of the liberal Catholic discourse on gender issues in Więź in the context of current Polish pastoral approaches to social dialogue on sexuality and gender diversity in Poland.

The analysis below provides commentary on sexuality and gender diversity is a reflection of the Church's need to be sensitive to people's interpretations and experience of the sexual sphere in the Polish society with the Catholic tradition and as a part of the whole Roman Catholic Church. Moreover, this article raises the question of non-heteronormative people in countries that witness the revival of traditional principles and right-wing political tendencies. This topic is relevant in the context of combining the pastoral approach and the Church's moral teachings. The matter concerns the Catholics who try to understand sexuality and gender in the context of faith and religion. According to the Church's thought, only some people understand their sexuality and gender (including the need to have sex) as a positive thing and not in contradiction with the teachings of the Roman Catholic Church, especially those of John Paul II. These include spouses who only have intermarital intercourse and people who are not in a sacramental marriage and abstain from sexual intercourse. ${ }^{4}$ In other words, only spouses or non-spouses live according to Church teachings and simultaneously experience their sexuality in a positive way; that is, they accept their sexual abstinence or marital fidelity. Given the circumstances above, this article introduces not only a theoretical scientific dimension but also a participatory value. The academic perspective grows out of Josephs Cardijn's theological method used in this article, along with a qualitative and quantitative analysis, and the evaluation of the problem of reconciling the experience of sexuality and gender with faith and religion as one of the main problems of modern Church and theology. The participatory perspective made me an academic participant and observer of social life in Poland and abroad. This article's participatory perspective employs Cardijn's method, which accentuates the social change. Thus, I offer this article with the hope that its conclusions will contribute to working out a more open social approach to sexuality and gender diversity, especially in pastoral Church activities.

For the reasons above, I present the Popes' and Polish Bishops' teachings, information about the Więź periodical, and my methodological approach. Then, I discuss the contents of the Więź. And finally, I conclude with concerns about pastoral postulates, propositions, and forecasted processes in Poland in debates about sexuality, gender, religion, and faith issues. My main research focus is on Wieź with some background information to set the scene, and I try to keep the participant perspective of pastoral and fundamental theology, combining it with the critical analytical approach.

\section{The Popes' and the Polish Bishops' teachings}

In the Roman Catholic Church, the current narration on sexuality and gender is shaped in reference to Pope Paul VI's encyclical Humanae vitae (1968) and Pope John Paul II's encyclical Veritatis splendor (1993). The two Popes condemn any sexual practices except for the ones between a man and a woman after the sacrament of matrimony. The importance of Humanae vitae was expressed in jubilee articles on the occasion of the fiftieth anniversary of its publication. ${ }^{5}$ Some researchers emphasize the social and theological

\footnotetext{
3 Odrowąż-Coates, "Gender Crisis in Poland," 27-34.

4 Veritatis Splendor, no. 47.

5 Cipressa, Sessualità, Differenza Sessuale, Generazione; Delicata, "Revisiting Humanae Vitae," 51-67; Chaput and Notare, Humanae Vitae, 50 Years Later; Curran, "Humanae Vitae,” 520-42.
} 
value of marriage and family, along with the bioethics dimension of human life from conception until natural death. ${ }^{6}$ Others indicate the fact that instead of ending the debate on artificial contraception and some sexual activities, Humanae vitae and Veritatis splendor have permanently revived this debate. ${ }^{7}$ Still, others prove that the Popes' thought is inconsistent with the latest state of research in biology, medicine, and gender studies, and therefore it has lost its relevance with regard to assessing morality in sexuality. ${ }^{8}$

The Popes Paul VI's and John Paul II's line of moral teachings was kept by the next Popes, Benedict XVI, and Francis. However, some pastoral changes were initiated toward non-heteronormative people in the Church $^{9}$ as signals appeared highlighting the need to take care of homosexuals as part of expressing love to wrongdoers and condemning sin. Pope Francis encouraged everyone, especially chaplains, to adopt a holistic approach toward the LGBTQ+ people, but a moral estimation of sexual activity with a person other than a spouse did not change. ${ }^{10}$ Many theologians positively assessed Francis's approach, ${ }^{11}$ but some expected greater changes in the liberalization of Church teachings. ${ }^{12}$

To summarize, the Church's thought is a source for Catholic's moral reflection on and evaluation of life. Traditional and progressive votes in the discussion on gender and sexuality in Church teachings continue. The traditional Catholic view has its supporters and opponents. Some researchers combine theology with feminist, LGBT, and queer studies, ${ }^{13}$ along with a transformation of Christian ethics. ${ }^{14}$ For example, some describe lesbian and bisexual Catholic women's narratives of religious and sexual identity formation and integration. ${ }^{15}$ Others reflect on individual women and their place in Catholicism. ${ }^{16}$ Still, others discuss the category of the body in Catholic tradition as an important part of gender issues in the Roman Catholic Church teachings. ${ }^{17}$

A change in pastoral thought and activity toward people who experience their non-heteronormative sexuality and non-traditional viewpoint on sexuality and gender should be seen. In fact, Pope Francis's approach should regulate pastoral transformations in local Churches. However, some bishops and priests in Poland oppose Pope's approach. Marek Jędraszewski, Archbishop of Krakow (one of the biggest cities in Poland), in sermons and interviews says that "LGBT is the third ideology of evil," after Nazism and Stalinism. ${ }^{18}$ Moreover, Jędraszewski compares non-heteronormative people to a cholera epidemic and Bolshevism, while LGBT "ideology" is to be a "mental plague" that attacks and threatens people. ${ }^{19}$ These statements were repeated by Mirosław Milewski, Auxiliary Bishop of Płock, who prayed during liturgy for Holy Mary's intervention against the spread of "sick LGBT ideology" that will strike traditional family. ${ }^{20}$

6 Hittinger, "Natural Law as Law Reflections,” 1-32; Smith (ed.), Why Humanae Vitae Was Right; Komonchak, "Humanae Vitae and its Reception," 221-57.

7 Curran, "Humanae Vitae," 520-42; Eberstadt et al., On Humanae Vitae Pope Paul VI; Melina, Sharing in Christ's Virtues; McCormick, "Some Early Reactions to Veritatis Splendor," 481-506; Thonheimer, "Intrinsically Evil Acts" and the Moral Viewpoint,” 1-39; Smith, Humanae Vitae.

8 Grimes, "Theology of Whose Body?," 75-93.

9 Homosexualitatis Problema; Catechism of the Catholic Church, no. 2358.

10 Amoris Laetitia, no. 250-1; In-Flight Press Conference 2016.

11 Biliniewicz, Amoris Laetitia and the Spirit of Vatican II; Salzman and Lawler, “Amoris Laetitia,” 634-52; Kelly, “The Role of the Moral Theologian in the Church," 922-48.

12 Martin, Building a Bridge; Keenan, "Receiving Amoris Laetitia," 193-212.

13 Althaus-Reid, The Queer God; Althaus-Reid, From Feminist Theology to Indecent Theology; Rudy, "Radical Feminism, Lesbian Separatism, and Queer Theory," 190-222; Rudy, “Queer Theory and Feminism,” 195-216; Alison, Faith Beyond Resentment; Alison, The Joy of Being Wrong; Stuart, Gay and Lesbian Theologies; Stuart, Religion is a Queer Thing; Stuart, Just Good Friends; McKee, "Resistance in hopeless," 235-49.

14 Rudy, Sex and the Church.

15 Houghton and Tasker, "Exploring Lesbian and Bisexual Catholic Women's Narratives," 47-69.

16 Sánchez, "Michèle Roberts’s Protagonists,” 229-44.

17 Jacobs, "An Alternative to Gender Complementarity,” 328-45.

18 Pitoń, “Abp Marek Jędraszewski nie odpuszcza.”

19 Kapela, "Biskup Jędraszewski.”

20 Czuma, "Biskup Milewski o LGBT.” 
Polish bishops conveyed their official narrative in a statement of the Polish Bishops' Conference on LGBT+ issues, published on August 28, 2020. ${ }^{21}$ After a 1-year-long preparation of the statement, the document included the idea of respect toward non-heteronormative people in the Church, ${ }^{22}$ condemnation of any form of violence against them, ${ }^{23}$ but also a postulate to "necessarily create counseling centers (with the help of the Church or with its structures) to serve people who wish to regain their sexual health and natural sexual orientation."24

A different approach is presented by Piotr Jarecki, Auxiliary Bishop of Warsaw, who believes that the Polish Bishops' Conference Statement is unnecessary. Jarecki also criticizes the idea of involving the Church in the promotion of the "Stop LGBT" law prepared by Fundacja Rodzina i Życie (Life and Family Foundation)..$^{25}$

The remarks above show that some bishops in Poland contradict Pope Francis's teaching. This discrepancy raises the question of the possibilities in the Polish Church for dialog on sexuality and gender diversity from the perspective of a pastoral approach. In providing an answer to this question, I analyze the Catholic sociocultural periodical Więź (Bond), which defines its goal as creatively and openly participating in social dialog on current topics. ${ }^{26}$ Therefore, the aim of this article is to present the results of my analysis of the liberal Catholic discourse on gender and sexuality issues in Więź. The outcome of my analysis can support detailed knowledge on debated gender and sexuality issues, their interpretation, and then answer the following question - Is social dialog on sexuality and gender diversity possible in Poland or is it only a set of right- and left-wing monologs without openness and sensitivity to statements of others? This question offers the possibility of change in the hierarchical and social Catholic narrative on non-heteronormative people from a pejorative one to a less judgmental and more empathetic one, i.e., the one promoted by Pope Francis. ${ }^{27}$ Moreover, the context of the discourse on sexuality and gender diversity in Poland results from the need for a better analysis on the following three questions: (1) How do we integrate sexuality with belief in God? (2) How do we positively deepen the relationship between religion and human sexuality? (3) How do we broaden the ability to speak with a spouse/partner about needs, experiences, and sexual impressions? There is a need to deepen reflection for commonly available, morally objective, non-violent, interdisciplinary, and scientifically honest thought on sexuality and gender in Poland. This expresses the need for theology of the ontic beauty of the body, sexuality, and gender in the Church. Some changes have already begun, popularized by Karol Wojtyła's, later Pope John Paul II's, theology of the body, ${ }^{28}$ whose idea emphasizes the importance of experiencing the body and sex as a space for communication between spouses. However, this approach does not develop the evaluation of sexuality and gender in human relationships outside matrimony.

The aforementioned questions apply not only to Polish Catholics. They help to diagnose the hierarchical Church's pastoral sensitivity in the whole Roman Catholic Church around the world. This universal Church recreates an approach to people with experiences that disagree with Catholic moral teachings. Moreover, this article's content may enrich the academic and social discussion on LBGTQ+ persons in countries that are witnessing a revival of strong traditional principles and a right-wing turn, signaled by the increasing political importance of such political parties as Prawo i Sprawiedliwość in Poland, Alternative für Deutschland in Germany, Freiheitliche Partei Österreichs in Austria, Front National in France, Vox in Spain, and Fidesz in Hungary. ${ }^{29}$

21 The Polish Biships' Conference.

22 Ibid., no. 27 and 29.

23 Ibid., no. 27.

24 Ibid., no. 38.

25 Jarecki, "Bp Jarecki."

26 Nosowski, "Historia Pisma."

27 Amoris Laetitia, no. 250-1; In-Flight Press Conference.

28 John Paul II, Man and Woman He Created Them; Wojtyła, The Jeweler’s Shop; Wojtyła, Love and Responsibility.

29 Haynes, "Right-Wing Populism and Religion,” 490; Kuzmics et al., "State, Emotion, Authority, and National Habitus," 9; Bieling, "Rise of Right-Wing Populism,” 78. 


\section{Materials and methods}

The periodical Więź has been an important sociocultural periodical in Poland during its publication. Więź was founded by Catholic laymen activists on the wave of a October 1956 political thaw, during the period of new hopeful reform of the communist system in Poland. The first issue appeared in February 1958. The goal was to actively participate in the intellectual revival of Polish Catholicism and open it to contemporary culture and new Western theological thought. The editors of Więź were unafraid to criticize negative phenomena in the Church in Poland, even if it meant entering a dispute with the Primate of Poland, Cardinal Stefan Wyszyński. Więź promoted "an open Church."30 The periodical seeks to not reinforce intra-ecclesiastical factions but instead to co-create a significant current in the Church life. As the editors claim, Więz aims to read the signs of the times and create critical contemporary Catholicism. ${ }^{31}$

Currently, Więź struggles with increasing competition on the Polish market of Catholic magazines. ${ }^{32}$ According to Tomasz Mielczarek, the journal belongs to a group of medium-circulation magazines in Poland published by non-governmental organizations that do not usually advertise but exist thanks to sales and subsidies from private people. The average circulation of such periodicals is approximately 3,000 copies with sales of about 2,000.33 In 2017, Więz was ranked fourteenth among the top twenty profiles that received the most funds in total on the crowdfunding service Patronite: the periodical received the amount of PLN 200,457. In terms of the amount of periodical support, it ranked fifteenth with PLN 9,705 per month. ${ }^{34}$ The journal archives its historical texts and makes them available online in open access. To access the newest editions of the periodical, payment is required. Due to theoretical assumptions and Więźs profile, the periodical represents open liberal Catholicism. It is the right source for tracing the evolution of discourse because it has existed for a long time, is regularly published, and is related to the tradition of democracy and support for pluralism in Polish society. Among other things, the latter means it creates a space for social dialog on the issue of sexuality and gender in the context of Roman Catholic faith.

To analyze Więź, I employed Cardinal Joseph Cardijn’s pastoral method and critical discourse analysis. As mentioned, the article is written from the point of view of pastoral and fundamental theology. Pastoral and fundamental theology enables access to the studied reality using methods of analysis from various disciplines of science. Pastoral and fundamental theology describes the current situation of the Church in which it carries out its activities. It is a theological-sociological or theological-psychological narration that is based on sociological, psychological, anthropological, or pedagogical research and covers issues related to the situation of the modern world in a global dimension, in various human societies and the situation of human beings. The conclusion of a research study in pastoral theology should be theoretical and practical, but it should be based on a methodically produced knowledge about the problem at hand, which is why I use the sociological method of critical discourse analysis. Pastoral postulates are formulated, including directives concerning activities in the studied area. According to these directives, the activity of the Church should aim at its self-realization now and in the future. These directives allow for the development of pastoral programs that adapt to the current situation. The use of Cardijn's method and critical discourse analysis to write an article on pastoral theology is justified.

Cardijn's pastoral method, which is popular in speculative and pastoral theology, comprises three steps: (1) "to see" means to observe and recognize context, situations, and phenomena so as to leave the position of a bystander, to leave one's own perspective and normativity, to achieve the most accurate and current information about an issue, and to try to see the issue as closely as it is possible; (2) "to judge" means to learn the details, to understand a nuanced thought in solidarity with people who experience the issue, and to formulate own views about the analyzed issue; and (3) "to act" means to elaborate and create

30 Frankiewicz and Gawryś, "Tadeusz w 'Więzi’," 80-8; Pasierb, "Walczyć nie z kimś, ale o coś,” 48-9.

31 Nosowski, "Historia Pisma."

32 Mielczarek, “Współczesna polska prasa opinii,” 80-102.

33 Ibid., 100.

34 "Więź zebrała na Patronite 200 tys. zł od czytelników 2020.” 
theoretical and practical conclusions and recommendations, to implement them in practice so as to alleviate suffering, to try solving problems, to bring interdisciplinary dialogue to fruition through praxis, and to change reality into a vaster and more beautiful life. ${ }^{35}$ This method was accepted by Pope John XXIII, and it gained an important position in the methodology of theology, ${ }^{36}$ which scholars and priests deem useful for those who describe the matters of inequality and "do not become either too abstract or too personal to be persuasive or effective." ${ }^{37}$ In Poland, this method is especially popular at the John Paul II Catholic University of Lublin, especially popularized by Władysław Piwowarski, Ryszard Kamiński, and Wiesław Przygoda. ${ }^{38}$ In this article, I present the Popes' and Polish Bishops' teachings, information about the Więz periodical, and a methodological approach for the "see" part of Cardijn's theological method. Then, I discuss the contents of the Więz in the "judge" part. And finally, I conclude in the "act" part by offering pastoral postulates, propositions, and forecasted processes in Poland in debates about gender and faith issues.

Carrying out the article's aim requires critical discourse analysis. The discourse is a communication event. On the one hand, it is shaped socially and culturally; on the other hand, it plays a role in shaping (consolidating or transforming) the current and future contexts of communication. ${ }^{39}$ In my research, I applied thematic analysis to identify the main themes of the socio-cultural discourses about sexual and gender diversity in the texts of the articles in Więz in the period under study. I was looking for the most strongly articulated content concerning sexuality and gender as broadly understood as possible to group them in clusters of interrelated meanings and explore their internal differentiation, sequence in time, and relation to other themes. The five identified Więź postulates are described following Cardijn's method.

\section{Results}

The study analyzed articles from Więź from 2007 to 2020, 82 issues in total. A double issue is classified as one (see Appendix 1). Before 2007, the gender themes were absent from the periodical as an independent subject..$^{40}$ I conducted a thematic examination in the form of a qualitative and quantitative content analysis of all issues of Więź from 2007 to 2020 that included one or more texts on sexual or gender-specific themes: $39.02 \%$ noted the gender or sexuality theme. In this context, it should be remembered that since 2013, Więź appears no longer monthly but quarterly. Additional quantitative analysis results are shown in the graph below (Figure 1).

Among the 2013-2020 issues, $46.88 \%$ includes content on sexuality or gender. This statistical datum demonstrates that the mentioned matters were - on average - more often discussed in Więź after 2013 than before that date.

Several themes of individual texts appear in Więź from 2007 to 2020. The themes are (1) bodily and spiritual pleasure (presented in one or more texts in four issues from 2007 to 2020; 4.88\% of all issues); (2) gender issues in the encyclical Amoris Laetita (7.32\%); (3) the theology of woman, feminist theology, including the priestly ordination of women (13.41\%); (4) homosexuality (9.76\%); (5) marriage and family (7.32\%); (6) nudity and the body (11\%); (7) sexual abuse in the Roman Catholic Church (7.32\%); and (8) moral dimension of using condoms (3.66\%). In some cases, the same Więź issue includes several specific subject matters (see Appendix 2). Therefore, the percentages above cannot be added up to $100 \%$.

35 Sands, "Introducing Cardinal Cardijn’s See-Judge-Act,” 2-4; Przygoda, "Paradygmaty metodologiczne we współczesności,” 33-6; Węcławski, "Metodologia Teologii,” 23-4.

36 Mater et Magistra, no. 236.

37 Sands, "Introducing Cardinal Cardijn's See-Judge-Act," 2.

38 Przygoda, "Paradygmaty metodologiczne we współczesności," 36-43.

39 Arcimowski et al., "Polski Dyskurs Publiczny," 82-6; Fairclough, Analysing Discourse; Starego, "Dyskurs," 26-36.

40 On the issue of sexuality and birth control in Więź in the sixties and later, see: Kościańska, "Humanae Vitae, Birth Control, and the Forgotten History,” 197-208. 


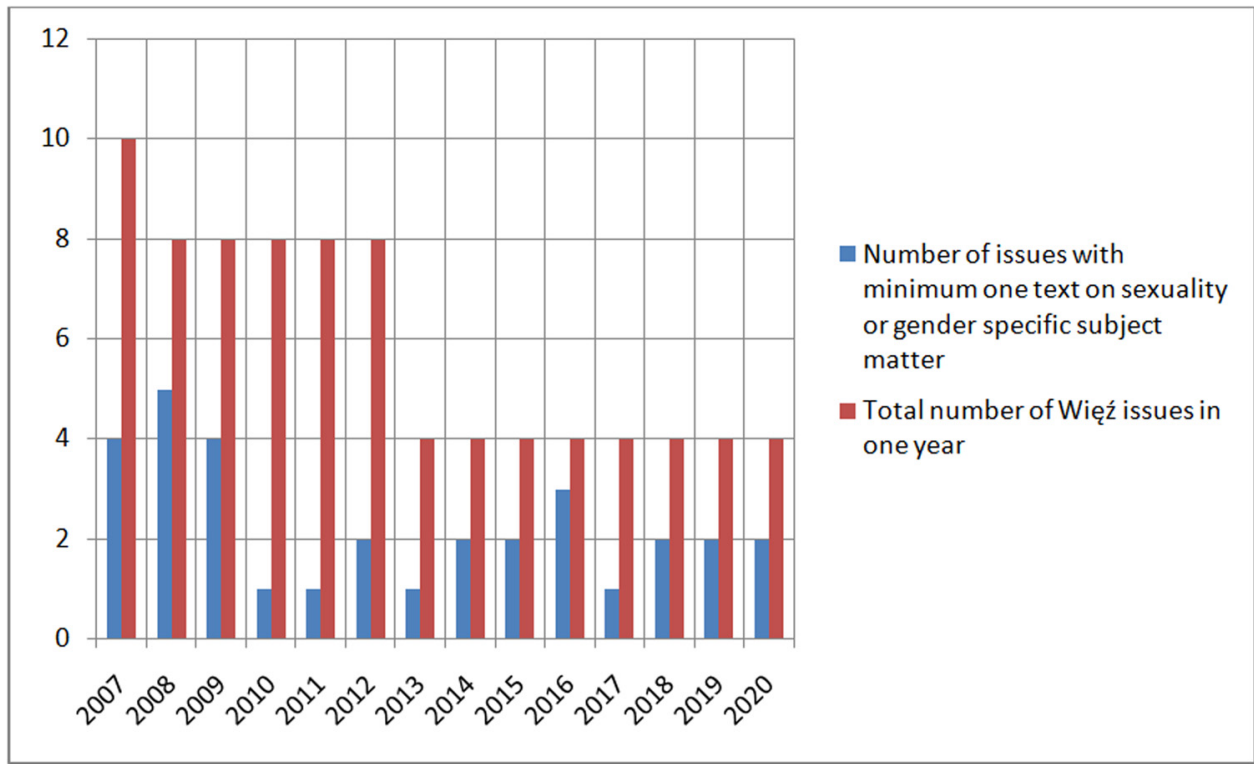

Figure 1: The proportion of Więź issues that offer texts focused on sexuality or gender to the total number of issues.

The analysis revealed that five volumes of Więz published in 2007-2020 correspond in a special way to sexuality and gender-related themes. There are several issues devoted to a specific theme, keeping in mind that each Więź issue typically has from one to three special themes (see Appendix 3).

Based on the qualitative analysis, I identified in Więź issues from 2007 to 2020 five main postulates on gender and sexuality stemming from various forms of reflection: articles, surveys, interviews, discussions, letters, personal confessions of non-heteronormative persons, and members of their families. The five postulates to consider are as follows: (1) a discussion about people with the need to revise their or the Church's narration on and experience of sex and gender; (2) the reevaluation of the significance and consequences of sexual revolution in Poland; (3) the proposal of a more mature, honest, and humanistic understanding of sex, sexuality, and gender than the one currently present in Poland; (4) the promotion and implementation of the idea of encounter; and (5) cases of sexual abuse in the Church.

\subsection{Noticing a discussion about people with the need for a revision of their or the Church's narration on and experience of sex and gender}

The first postulate identified in the analyzed Więz issues concerns the recognition of the self-narration of people who experience their sexuality and gender in the context of faith in God. According to the Church's thought, only spouses or non-spouses live according to Church teachings and simultaneously experience their sexuality in a positive way; that is, they accept their sexual abstinence or marital fidelity. The observation above shows that there is a group of people who do not have such characteristics. This means that this group consists of individuals who have - in the language of moral theology - "a disorder of the will." ${ }^{41}$ According to the Więz authors, an individual with the disorder of the will can arrive at two conclusions: (1) the need to revise the teachings of the Roman Catholic Church and (2) the need to review his or her life. Both conclusions appear to notice the need for revision. As emphasized in Więź, it is important to remark that the need to revise one's life does not mean a stagnation of sexuality, nor does it mean coercion toward a normative gender identity. It entails an individual's and Church's reevaluation, a change of 
perspective, and a new look at sex, sexuality, and gender in general in the context of one's faith and relationship with God.

In Więź, it is emphasized by a theologian and ethicist from the John Paul II Catholic University of Lublin, Alfred Wierzbicki:

\begin{abstract}
We should not deem the search for solutions disallowed by John Paul II a betrayal of John Paul II. [...] It seems that the light with which we can settle the issue of Holy Communion for the divorced in a spirit of mercy cannot appear in the field of considerations about the indissolubility of marriage, because the latter clearly shows a violation of the norm. Rather, the relevant area would be a reflection on the Eucharist: is it a reward for good life or a sacrament that lifts a sinner who - in the face of a wrongful breakdown of his earlier marriage - continues living the Gospel in a situation that can no longer be changed? [...] The Church has not yet found answers to these questions but refraining from searching for answers will certainly not bring us any closer to a solution. Faithfulness to John Paul II requires the assimilation of both the content of his teachings and the method through which he developed and refined his views, striving for co-interference with the deposit of faith and at the same time facing new challenges that requiring the courage of thought. ${ }^{42}$
\end{abstract}

Wierzbicki presented a methodological and pastoral point in terms of reevaluation of the approach to sexuality toward religion and faith. Confirmation of its legitimacy in Więź is offered by Jerzy Sosnowski, a writer, essayist, and member of The WIĘŹ Laboratory: Institute for Social Analysis and Dialogue:

I have the impression that Catholic ethics, treating their nineteenth-century traditions with unjustified reverence, still have problems with justifying the sexual act, as if there was no Song of Songs in the Holy Bible (in Catholic commentaries to the Holy Bible we find touching attempts to prove that the description of Shulamite's breasts actually only refers to the hills on which Jerusalem was built!). A dramatic testimony of these troubles for Catholic consciences is the encyclical Humanae vitae, which I invariably consider one of the biggest mistakes of twentieth-century popes. ${ }^{43}$

The postulate of a need for revision is also clearly elicited by psychotherapists who write in Więź. In a poll conducted by the magazine, a therapist from Stowarzyszenie Psychologów Chrześcijańskich, Lena Wojdan, writes:

\footnotetext{
Almost all parents who come to my office come with the same question: "What should we do to change our child? We do not want it to be homosexual!" [...] I agree to the meeting, but I loyally warn the parents that I do not intend to be their spokesman. The attitude "you are homosexual; come, I will change you" is beyond me. I think instead, "I am here, I believe that God created you heterosexual (Genesis 1:27-31), if it is also important for you, if you are ready - I am waiting.” [...] I respect that because I believe that God also gave you freedom..$^{44}$
}

The therapist's voice is presented in Więź as important in the need to rework the approach to understand the linking of sexuality and gender with religion and faith. The thought reappears in the confession of an anonymous father of a homosexual son. The father describes the change that parents undergo when they learn about their children's non-heteronormativity. He declares that as a part of the change, he accentuated honesty with God and himself. His aim is to reconcile faith and his son's identity. ${ }^{45}$

To summarize, the need for individual or Church revision is noticed and articulated in Więź. According to Więź authors, the logical consequence is methodological and pastoral reflection on the development of theology and ministry. Such a result will open the Church more to individual life stories which not infrequently have a dramatic course.

42 Wierzbicki, “Odwaga myślenia według Wojtyły,” 131.

43 Sosnowski, “Niegrzeczna Pobudka,” 36.

44 Jabłońska, "Pomiędzy," 10.

45 Ibid., 18-9. 


\subsection{Reevaluation of the significance and consequences of sexual revolution in Poland}

The second dominant postulate on gender and sexuality in texts from Więz focuses on the issue of sexual revolution. Więz is published in Polish, so writing about the significance and consequences of the sexual revolution initiated in 1968 is mainly seen from the perspective of Polish experiences and observations. Many articles remark that no sexual revolution occurred in Poland since the 1960s. There also was no delayed sexual revolution. There only occurred an evolution that stretched over decades, which requires further development. This statement is emphasized in Więź issues from 2007 to 2020, especially in the double issue from 2008, no. 7-8, dedicated to the evaluation of sexual revolution in Poland. The idea is emphasized in a survey conducted for this issue and in an article by Bartłomiej Dobroczyński “Żadnej rewolucji nie było." ${ }^{{ }^{6} 6}$ This interpretation of the recent history of Polish customs may change in later Więz issues because of the protests in Poland since October 2020 against abortion law restrictions. In public discussion at one point, some proposed to call the protests a proper sexual revolution like the one that happened in the USA and Western Europe in $1968 .{ }^{47}$ However, an assessment of whether this social disagreement became a sign of a rapid mental change or an expression of a desire to return to the previous legal status should be the subject of another study.

According to the Więź authors, changes in Poland since 1968 refer to material, media, and consumer culture, in which bolder images and words about sex began to appear openly. However, there appeared a minor change in attitudes, called in Więź an evolution, but not a revolution, which resulted in the lack of satisfactory, commonly available, morally objective access to interdisciplinary, non-violent, and scientifically honest solutions about sexuality and gender. Among other things, Więz authors developed three important questions: How do we unite sexuality and gender with belief in God? How do we deepen the relationship between religion and human sexuality? How do we learn the ability to speak with other person about needs, experiences, and sexual impressions?

The example of a statement about the non-obvious sexual revolution in Poland and the need for changes in experiencing sexuality appears in Zbigniew Nosowski's summary of texts gathered in the Więź issue from 2008, no. 7-8. He quotes Piotr Bratkowski, a poet, literary critic, and journalist: "More and more often the heroes of our culture are not passionate lovers but sexologists. This is proof that the sexual revolution of the 1960s failed." 48 Next, Nosowski suggests that the need for a continual sexual evolution in society and the Church is enormous. He proposes a sacramental vision of eroticism as a compelling alternative to the destructive forces of potential new revolutions and a new approach for theology, preaching, relations, spirituality, and faith. ${ }^{49} \mathrm{He}$ suggests that eroticism should be analyzed as the mutual dedication of two people in marriage, modeled on the inner life of Godhead, a timeless community of giving and receiving:

In this perspective, mysticism and eroticism are close to each other. [...] Sex can be sacred because the love of marriage expresses the greater, the greatest Love. Marital intercourse can be sacred as an expression of sacred, sacramental, conjugal love, as an opportunity to meet God and the spouse. ${ }^{50}$

Based on Nosowski and other Więz authors, it should be noted that the sexual evolution in Poland that began in 1968 concerns changes in the pastoral approach of the hierarchical Church and the awareness of the laity. This process has already begun. However, it requires a deepening by theologians, priests, and believers in the field of sexuality and gender. This reflection informed the third postulate present in

46 Dobroczyński, “Żadnej rewolucji nie było,” 5-9.

47 Drelich, "Spóźniona rewolucja seksualna;” Bosomtwe, "Kiedyś zakaz rozwodów, dziś wolna aborcja.”

48 Nosowski, "All You Need is Sex?,” 75.

49 Ibid., 82.

50 Ibid., 79. 
Wię $z$ - the formation of more mature, honest, and humanistic understandings of the sexuality and gender spheres.

\subsection{Proposal of a more mature, honest, and humanistic understanding of the body, sex, sexuality, and gender}

The third Więź postulate concerns the proposal of a more mature, honest, and humanistic understanding of the body, sex, sexuality, and gender. It means a more holistic approach in relation to all aspects of being human. The listed features are not literally enumerated by Więź authors but implied by their statements, as the authors express a need to better understand the body, sex, sexuality, and gender. They do not formulate detailed proposals, holistic programs, or elaborate definitions for this issue, but their texts offer examples of a better approach to these matters. They propose that the understanding of the four areas should be more mature, honest, and humanistic. That is, this understanding should account more for scientific knowledge about humans, be more clearly aware of the ontic beauty of carnality and sexuality, and acknowledge the many difficulties in examining human identity. Moreover, it should not be determined by a particular religion and its moral teachings or a theoretical, notional debate about sexuality or gender but rather focus more on people and their experiences. These features are evaluative, which is not by accident because the Więź authors assess and evaluate the state of the current approach to sexuality and gender in Poland. They judge this approach as unsatisfactory and provide examples of how it should be changed. According to the Więź authors, the appeal for a more mature, honest, and humanistic understanding is addressed to all. In other words, in the context of experiencing faith, this appeal applies to the hierarchical Church (the clergy) and the whole community of the Church (all baptized people). By expanding this perspective, the commitment to deepening social and individual knowledge of the body, sex, sexuality, and gender also applies to representatives of non-Christian religions and people who do not identify with any ecclesial community.

A desire for what is perceived as a more mature, honest, and humanistic understanding is a part of the deepening of knowledge that is necessary for a more conscious experience of oneself and others, a more articulate expression of one's needs in the area of the body and sexuality, and a more articulate shaping of one's relationship with God. Such an approach invites countless possibilities for every human being to experience a united body and spirit. Więź presents voices that discuss this problem, e.g., Zbigniew Izdebski's diagnosis:

As Poles, we are little aware of our sexual rights. We declare to be satisfied with our sex life but probably because we are undemanding in this area [...]. Moreover, we live in the times of AIDS, when by far the most infections are caused by risky sexual behaviors. Undoubtedly, reliable sex education for people in various stages of life is very much needed, and we do not have that in Poland. ${ }^{51}$

In addition, a psychotherapist and priest, Jacek Prusak, states in Więź the need for a new sexual revolution, for a deeper sexual and gender awareness in the Roman Catholic Church:

In a positive sense, the sexual revolution makes modern people aware [...] that the choice they make more or less consciously often concerns the choice between religion and eros. In my opinion, however, we never managed to overcome this dichotomy, but we only made it more pronounced. I believe that a "sexual revolution" can only happen when it will be open to the Spirit, because [...] the libido theory shows, sexual energy is not just "natural," it does not come true by itself. [...] sexuality is not plastic like rubber, nor is it an unnecessary addition. However, the Church awaits its own "sexual revolution." 52

51 Izdebski, "W Polsce wolniej," 23-4.

52 Prusak, “Ta rewolucja wymaga Ducha,” 30-2. 
Let me note that in the issue 2008, no. 7-8, there appear several articles that signal these matters - e.g., "Wciąż mało wiedzy" by Barbara Fatyga, ${ }^{53}$ "Jeszcze seksowniejsza rewolucja" by Aneta Gawkowska, ${ }^{54}$ and “Ewolucja w rewolucji” by Jerzy Grzybowski. ${ }^{55}$

Moreover, Więź independently tries to improve social awareness of the body, sex, sexuality, and gender. For this purpose, the periodical dedicated several issues to this matter in special issues (see Appendix 3). Furthermore, sociologist Aneta Gawkowska offers a poetic, and theological voice on the body, sex, sexuality, and gender. She tries to increase Więź readers' awareness of the sexuality sphere: "From the perspective of Heaven, bodies connected by total and exclusive love are a substitute for a loving and cosmic madness that occurs during the eternal wedding feast after human deification."56 Theologian Sebastian Duda presents an analogical approach. Like Gawkowska, he poetically and theologically states that nudity juxtaposed with the sacred will not cause any scandal after the eschaton; therefore, experiencing the body (including sexuality) is an element of salvation. ${ }^{57}$ In my view, Gawkowska's and Duda's statements provide an adequate language that combines theological and sexuality-based narration by emphasizing the ontological beauty of the body, sexuality, and gender through elegant poetic phrasing. This may be a relevant proposal for a new language to speak about the above-discussed matters.

As my study revealed, Więź authors diagnose a need for a new understanding of the body, sex, sexuality, and gender and offer content that can positively respond to this need. Based on the detailed analysis performed in my research, I can indicate one postulate that especially clearly shows Więźs attempt to deepen public reflection on sexuality and gender: the promotion and implementation of the idea of encounter.

\subsection{Promotion and implementation of the idea of encounter}

According to Więź, the encounter appears in several dimensions: that of a human being with oneself, a human being with another human being, a human being with society, and a human being with God. It is hard to say which one prevails. Ideally, they do not fight each other. They interpenetrate each other. For example, one human being's relationship with society affects his or her relationship with oneself (the social self-image), and one human being's relationship with oneself influences one's relationship with God.

As I mentioned above, the idea of encounter offers a way to deepen the understanding of sexuality and gender. In the context of people with different sexual identities, this encounter becomes an opportunity to learn from each other. It is also a chance to move away from the assessment of other gender identities with prejudice.

Such an idea of encounter is articulated in two ways: as a Więźs proposition and practice (in Więź debates). The proposition appears in a text by Bartosz Bartosik, a member of the editorial board of Więź and a secretary of the think tank Laboratorium WIĘZI:

And yet, in Więź, we are convinced that we should reflect and talk about building a community and, above all, we should act [...] it seems that we will have to face an unprecedented challenge. We cannot deal with it effectively by only using individual survival strategies, but we will need a vision of communality or at least that of thinking in terms of the common good. So as to avoid a utopia of a community of all Poles, we must assume that - as we differ from one another - we must live together here and now, not only beside each other. And we must jointly consider the problems of the melting world..$^{58}$

An example of a practical articulation of the idea of encounter appears in Katarzyna Jabłońska's interview with a transgender person, Ewa Hołuszko. When writing about her social and spiritual relations in the context of her gender identity experience, Hołuszko says:

53 Fatyga, "Wciąż mało wiedzy," 11-2.

54 Gawkowska, "Jeszcze seksowniejsza rewolucja," 13-6.

55 Grzybowski, "Ewolucja w rewolucji," 19-22.

56 Gawkowska, “Jeszcze seksowniejsza rewolucja,” 14.

57 Duda, “Zgorszenie, wstyd i prawda," 193-4.

58 Bartosik, “Polskie życie bardziej wspólne,” 31. 
I did not tell anyone because I did not want for this difficult to understand matter - then much more than today - to shake others' trust in me. I only talked about it with God. I wasn't deceiving God; I could be myself before Him. But not before people, I couldn't tell the confessor either. Today I can, but also not everyone. [...] If it weren't for the grace of faith, I wouldn't be talking to you today. But what about those who do not have it or who reject God? It is hard for me to imagine such loneliness. ${ }^{59}$

Other examples of the practical implementation of the idea of encounter to better understand sexuality and gender are encounters gathered in the Więź issue from 2007, no. 10. This issue includes fragments of talks with non-heteronormative children's parents with Katarzyna Jabłońska (a psychotherapist), one father's rich, year-and-nine-month-long correspondence with Cezary Gawryś (a journalist and a publicist), and e-mails between a homosexual person and a famous priest, talks with Jacek Prusak SJ, Cezary Żechowski (a child psychiatrist), Katarzyna Jabłońska, and Cezary Gawryś. All texts present the encounter as a space for a rescue from the lonely and difficult experience of one's sexuality, and a space that allows for a better and deeper understanding of one's sexuality and gender. These texts show that non-judgmental communication with others has an educational, humanistic, and pastoral value. Such communication may teach openness, sensitivity, and understanding for non-heteronormative people and offer insight into their frequently dramatic experiences and the significance of sexuality and gender in one's relationship with themself, other human beings, society, and God. Consequently, Więź's idea of encounter may be interpreted as an attempt to combine religion, faith, social, and individual approach in the context of sexuality and gender.

\subsection{Cases of sexual abuse in the Church}

The four aforementioned postulates may be interpreted as an approach to better understand the body, sex, sexuality, and gender, while also implementing the idea of encounter. The fifth postulate can be seen as different from the other four. It concerns the cases of sexual abuse in the Church. It creates a new problem of understanding sexuality and gender, and it will be necessary to (1) confirm or revise the current teaching on sexuality in the Church (e.g., on celibacy) and (2) redefine what in sexuality and gender diversity is covered by the encounter paradigm, and what is not.

The first analyzed issues of Więz from 2007 to 2020 mention the theme of sexual abuse in the Church by referring to reports on pedophile priests in the West (e.g., Ireland and the USA). ${ }^{60}$ The same subject concerning the Church in Poland emerged after the publishing of journalistic investigations in the Sekielskis documentary films Tylko nie mów nikomu (Tell No One, 2019) and Zabawa w chowanego (Hide-and-Seek, 2020). Published information - often against the bishops' will-about cases of sexual abuses in the Church in Poland elicited a reaction from the Polish society, including the Więź editorial team. The latter's answer to the increasing number of victims' voices and journalistic reports appeared in the issue Kościót rozliczany i przejrzysty (The Church Held Accountable and Made Clear) from 2019, no. 1, and part of the issue Kryzysy naszego Kościoła (Crises of Our Church) from 2020, no. 3. The social discussion about the current Roman Catholic Church in Poland continues after Piotr Kraśko's interview with Cardinal Stanisław Dziwisz about circumstances of pedophilia in the Church during John Paul II's pontificate (2020) and Marcin Gutowski's journalistic report Don Stanislao: Druga twarz Stanisława Dziwisza (Don Stanislao: The Other Face of Cardinal Dziwisz, 2020) on the same topic. ${ }^{61}$

59 Hołuszko, "Boga nie okłamywałam,” 69.

60 Majewski, "Przerażające dane o księżach pedofilach,” 126. All the issues: Więź, 2008, no. 6. Więź 2011, no. 8-9. Więź 2014, no. 1. Więź 2015, no. 1.

61 Mandes, “Clerical Sexual Abuse,” 110-34; Guzik, “An Unfinished Story of Conversion,” 417-45; Rezmer-Płotka, "Activities of the Catholic Church,” 359-71; Tworzydło et al., "Catholic Church in Poland,” 157-72; Dziaczkowska, “The Polish Case,” 235-51. 
Two conclusions appear in Więź on the matter: (1) understanding for the tremendous suffering of victims and the need for a broadly understood compensation; (2) the need to identify and punish the persons guilty of pedophilia and its cover-up. These two ideas appear in Więź differently than previous issues. So far, the periodical mainly published Polish theologians, priests, journalists, publicists, and other participants of Polish cultural and social life. The issue Kościót rozliczany i przejrzysty from 2019, no. 1, offers essays by foreigners who represent credible voices from the West, which experienced the shock of revelations of Church pedophilia earlier than Poland and had to work out methods to enforce justice. These authors are Cardinal Luis Antonio Tagle (since 2011, the Archbishop of Manila, president of Caritas Internationalis), Cardinal Blase Cupich (the Metropolitan Archbishop of Chicago; since 2014, a member of the preparatory committee of the Vatican Meeting on the Protection of Minors in the Church), Linda Ghisoni (Doctor of Canon Law; since November 2017, the undersecretary of Dicastery for the Laity, the Family and Life), Cardinal Reinhard Marx (the Archbishop of Munich and Freising; since 2014, the president of the German Bishops' Conference), and Valentina Alazraki (Mexican journalist; since 1974, a correspondent for Televisa in Rome and the Vatican).

One of the exponents of Więź's postulate to solve cases of sexual abuse in the Church is Valentina Alazraki, whose speech at the Vatican Meeting on the Protection of Minors in the Church, February 23, 2019,62 calls upon the bishops of National Episcopal Conferences for an unequivocal answer:

In facing criminal conduct such as the abuse of minors, do you think that to be true to herself, an institution like the Church can have another way if not that of reporting this crime? That she can have another way if not that of being on the side of the victim and not that of the oppressor? Who is the weakest, most vulnerable child? The priest who abused, the bishop who abused and covered up, or the victim? [...] if you do not decide in a radical way to be on the side of the children, mothers, families, civil society, you are right to be afraid of us, because we journalists, who seek the common good, will be your worst enemies. ${ }^{63}$

It is likely that the topic of sexual abuse in the Church in Poland will appear in further Więz issues. It is highly likely that the periodical will continue to articulate the expectations for understanding the suffering of victims, their compensation, and identifying the guilty. It is possible that Więź authors will present additional social expectations, which may propose a reform in the financing of the Church from the state budget.

To summarize, the five indicated postulates are connected and include the eight identified themes of individual texts in Więź from 2007 to 2020. The need for revision comes from Więźs discovery of the insufficient reconfiguration of sexuality and gender in the Church and individual narration and experience, which introduces the need for a deeper understanding of the body, sex, sexuality, and gender through the idea of encounter for a better and more mature relationship with oneself, other human beings, society, and God. The last postulate by Więź concerns the judgment of cases of sexual abuse (especially pedophilia cases) in the Church. The settlement of the abuse should be a part of the sexual revolution in the Church. It should be accompanied by a withdrawal from clericalism and corporate Church-thinking, which makes it difficult to understand the enormity of the harm done to the victims and their dramatic experience of sexuality.

\section{Discussion}

Więź develops important social and theological themes about the body, sex, sexuality, and gender, and it uses various forms of reflection that could be employed in other social periodicals: articles, surveys, interviews, discussions, letters, and personal confessions. Because of this, Więź is more interesting for readers.

62 Alazraki, “Któż jak nie biskupi ma to zrozumieć?,” 154-63.

63 Ibid., 155-6. 
Of particular importance are letters and testimonies through which readers can indirectly meet people who articulate their experiences of gender and belief in God. The statements of therapists (secular and clerical) are especially important. The therapists do not make any moral assessments. They show the often dramatic experiences of heteronormative and non-heteronormative people, which do not agree with the teachings of the Church on sexuality and gender.

On the basis of Więź texts, I conclude that the periodical implements Cardinal Joseph Cardijn's pastoral method. ${ }^{64}$ Więź implements three steps of the pastoral method: (1) "to see," (2) "to judge," and (3) "to act."

The language of expression requires separate attention. The Więz debates' participants are polite but should notice more gender diversity than they do. Many Więź issues address the issue of gender, the number of women in the Church, the feminization of culture, the theology of the body, and experiences of sexuality. However, queer, intersex, and asexual people remain unmentioned. Maybe Więź editors believe these themes are too controversial for their readers, or it could be these matters have not yet been noticed by Więź authors at all. However, I believe that this should change so that the periodical shows a wider spectrum of specific sexuality- and gender-related themes. ${ }^{65}$

It should also be noted that Więź articles present opinions by people who both agree and disagree with moral teachings of the Roman Catholic Church. They often do not reach complete agreement; however, the dialog itself can be read as an attempt to learn how others think. These encounters and dialogs should be oriented toward stimulating sensitivity, cordiality, love of one's neighbor, deepening of one's faith, and mutual accepting between interlocutors. This apparently trivial observation is not easily applied in practice. It seems that the problem in social and Church communication about sexuality and gender stems, among other things, from the lack of awareness about the depth and significance of sexuality and gender. Moreover, Polish bishops seem to treat these matters as beyond their everyday experiences and beyond the experience of those Catholics who follow the teachings of John Paul II. In other words, the attitude of some bishops may result from a lack of opportunities or will that would require them not to meet for preaching, teaching, or judging, but for hearing, learning, understanding, and deepening their awareness of sexuality and gender issues from others' testimonies and research.

The bishops' approach is inappropriate and harmful from social and theological perspectives, which includes statements by some Polish Church hierarchs who harm non-heteronormative persons by proposing they change their sexual orientation, reducing them to an ideology or calling them a plague, as quoted in the introduction to this article. In this context, the five Więz postulates seem to be even more important to the current and future Church's social narration on sexuality and gender. The postulates inform us that the need for sexual education in the Church and the Polish society is enormous. They also suggest certain solutions, the most important one being the implementation of the idea of encounter. ${ }^{66}$ This idea has several values: (1) it saves us from the lonely and often difficult experience of one's own sexuality and gender identity; (2) it constitutes the sphere of asking questions and looking for answers on sexuality and gender in faith and religion; (3) it enriches us socially, spiritually, and psychologically; (4) it sensitizes us to others and their similar or different experiences of sexuality and gender identity; (5) it creates a sense of dialogue and community among us; (6) it broadens our sensitivity to social gender differentiation and individuals' experiences; and (7) it makes us aware of how many areas of life are influenced by sexuality and gender-related matters.

How may we implement the idea of encounter? In the current Polish context, this idea should not be realized as a nationwide pastoral plan in the Church or an educational program at schools. The pastoral plan must be drafted by the Polish Episcopal Conference and implemented by priests during sermons. As Więź signalizes, the Church in Poland needs a reconfiguration of its narrative and attitude to the body, sexuality, and gender. Thus, the Church should not institutionally and structurally reform Polish society. Moreover, until the Church addresses its pedophilia scandals, it will lose social trust and its mandate for

64 Sands, "Introducing Cardinal Cardijn's See-Judge-Act," 2-4.

65 Confer. Jawor and Kurowicka (eds.), Polska transformacja seksualna.

66 Confer. Haffner and Ott, A Time to Speak; Hinze, Practices of Dialogue in the Roman Catholic Church. 
institutional education on sex. ${ }^{67}$ Educational programs at schools would also likely fail in most cases. In Poland, lessons about family life are frequently taught by teachers of religion. Their work as the teachers of the both lessons is not banned by the state or Church law despite the possible conflict of interests. These reasons undermine the legitimacy of conducting meetings on sexuality and gender as part of the Church's or school's educational program.

Więź texts show that the implementation of reflection about the body, sex, sexuality, and gender indicates a greater need for bottom-up work: every person in Poland (believer and non-believer) should increase their awareness of sex and gender and experience an encounter with people of diverse gender identities. As it can be seen, Więź not only indicates the need for a better understanding of the body, sex, sexuality, and gender but also proposes content that can positively respond to this need. Więź does not offer a full educational or state program but instead suggests examples for discussion such as education on AIDS, the connection between spirituality, eroticism, and sexuality, the understanding of non-heteronormative people's identity, and their experience of faith.

Texts in Więź also suggest that adults and teenagers who are mentally ready for a discussion may meet psychologists, psychotherapists, sexologists, and persons who experience a deep understanding of their own sexuality and gender in relation with themselves, other persons, society, and God. ${ }^{68}$ The aforementioned need for bottom-up work shows that each person should be a partner in the Polish society's dialog on sexuality and gender. The right space for an encounter may be formation meetings organized by nongovernment organizations, Church communities such as the Domestic Church (family branch of the LightLife Movement), or the Catholic Youth Association. These communities can organize regular or occasional meetings with special guests - psychologists, psychotherapists, sexologists, and other persons with a deep understanding of sexuality and gender issues - to debate, inquire, and seek the theological (and nontheological) significance of the body, sex, sexuality, and gender. Texts in Więz show that these meetings should not only be lessons in reading and confirming the Catechism of the Catholic Church's rules or John Paul II's thought. This approach does not satisfactorily answer individual queries, anxieties, or contestations. If it would, there would be no theological questions at all.

In the above context, the significant potential of the laity should be emphasized. One sign of the Church in modern times is not the episcopate or the catechism but the people and their needs, experiences, joys, and sorrows articulated and displayed in mass and social media. The people active in the local and global Church make demands of and affect this institution. Thus, they have a chance to provide their own suggestions for the present and future of the Church.

\section{Conclusion}

In this article, the Apostolic See teaching on sexuality and gender, especially non-heteronormative gender, was shortly presented. Then, the chosen Polish bishops' statement on homosexual persons was shown. Next, the history and profile of Więź magazine were demonstrated. Joseph Cardijn's pastoral method was displayed. In the next part of the article, there was a discussion of the analysis from the 82 issues of Więź from 2007 to 2020. The thematic analysis results were presented as qualitative and quantitative content analysis. The statistical data and the specific themes were articulated. Then, the five indicated Więź postulates in the context of sexuality and gender were exhibited. The conducted analysis became the basis for submitting several conclusions which constitute the implementation of the Cardijn's pastoral method "act" part.

67 Przeciszewski, "Spada zaufanie do Kościoła."

68 As an attempt to conduct such meetings, we may consider the webinars from November and December 2020 "Otwarcie wokół seksualności. Cykl spotkań z młodzieżą” (An Opening for Sexuality: A Series of Meetings with the Youth, designed by Maja Jakóbczyk and Klaudia Grzyb from the SWPS University in Wrocław; SWPS University, “Otwarcie wokół seksualności.”). 
Implementing the conclusions from the previous discussion gives us a chance for social dialog on gender and sexuality. These suggestions do not represent the full range of possibilities of the positive impact of this dialog. Nevertheless, as I suggested above, one of the key ways to reinforce this dialog lies in the implementation of Cardinal Joseph Cardijn's pastoral method, ${ }^{69}$ and critical discourse analysis which I used in this article and which I noticed in the editorial practice of Więź. The method helps us to understand the nuances of the analyzed question (in this case, the individuals' experience of the body, sex, sexuality, and gender). Without the Church's understanding of such nuances, its renunciation of a monologic disposition, and its opening toward others in the present public dialog and pastoral approach to sexuality and gender diversity, any change in the Polish Church seems to be impossible or at least highly unlikely.

The analysis of the Catholic sociocultural periodical Więź from 2007 to 2020 shows that it can be a space for public debate. Sometimes this debate ends with no consensus, but the exchange of thoughts articulated with respect for the other remains a worthwhile experience and an opportunity to potentially open people's minds and hearts to non-heteronormative people and gender diversity. The application of the indicated Więź postulates - especially the idea of encounter that can help implement other postulates - will positively contribute to a real public dialog on gender diversity in modern Poland. If those who shape attitude in the Church - some bishops, priests, but also politics and people of culture - continue speaking in a judgmental manner and do not adopt a more personalistic and empathetic style of communication that embraces openness and sensitivity to gender-different people, such a call for public dialog will probably remain but a lofty utopia. As a consequence, an even greater polarization of attitudes and narratives in Poland will emerge, leading to stronger social tensions and perhaps also personal tragedies.

This prognosis may be adequate not only for the society and Church in Poland but also for LGBTQ+ people in other countries with strong anti-gender diversity narratives and political right-wing advocates. Moreover, the state can also affect the lives of heteronormative people with a non-traditional viewpoint on sexuality and gender diversity. Therefore, openness to others and true encounter with them should be interpreted as responsible and necessary action.

Acknowledgments: The author thanks Marta Bucholc (the University of Warsaw) for scientific support in writing this article.

Funding information: This research was funded by the National Science Centre in Poland, grant "National habitus formation and the process of civilization in Poland after 1989: A figurational approach," SONATA BIS, no. 2019/34/E/HS6/00295.

Conflict of interest: The author declares no conflict of interest. The founders had no role in the design of the study; in the collection, analyses, or interpretation of data; in the writing of the manuscript; or in the decision to publish the results.

Data availability statement: Some of the primary sources - meaning texts published in Więźz-are available online: https://wiez.pl/wydawnictwo/kategoria/kwartalnik/. The data are stored by Więź.

\section{References}

Alazraki, Valentina. “Któż jak nie biskupi ma to zrozumieć?” Więź 62:1 (2019), 154-63. Alison, James. The Joy of Being Wrong. Original Sin Through Easter Eyes. New York: Crossroad Publishing Company, 1998.

69 Sands, "Introducing Cardinal Cardijn’s See-Judge-Act," 2-4; Przygoda, "Paradygmaty metodologiczne we współczesności," 33-6; Węcławski, “Metodologia Teologii,” 23-4. 
Alison, James. Faith Beyond Resentment, Fragments Catholic and Gay, London: Darton, Longman and Todd, 2001.

Althaus-Reid, Marcella. The Queer God. Abingdon, Oxon: Taylor and Francis, 2004.

Althaus-Reid, Marcella. From Feminist Theology to Indecent Theology. Readings on Poverty, Sexual Identity and God. London: SMC, 2004

(Amoris Laetitia) Francis [the pope]. Encyclical Amoris Laetitia. Rome: Libreria Editrice Vaticana, 2016.

Bartosik, Bartosz. “Polskie życie bardziej wspólne.” Więź 63:4 (2020), 31-9.

Bieling, Hans-Jürgen. "Rise of Right-Wing Populism in the Europe of Today - Outlines of a Socio-Theoretical Exploration." Culture, Practice \& Europeanization 4 (2019), 78-91.

Biliniewicz, Mariusz. Amoris Laetitia and the Spirit of Vatican II. The Source of Controversy. London; New York: Routledge Taylor \& Francis Group, 2020.

Bosomtwe, Oliwia. “Kiedyś zakaz rozwodów, dziś wolna aborcja: Czy Polska pójdzie w ślady Irlandii?” Noizz, 2020. Accessed: January 20, 2021. https://noizz.pl/spoleczenstwo/od-zakazu-aborcji-do-dostepnej-aborcji-czy-polska-zmieni-sie-jakirlandia/93zg540

Chaput, Charles, and Notare, Theresa. Humanae Vitae, 50 Years Later: Embracing God's Vision for Marriage, Love, and Life: A Compendium. Washington D.C.: The Catholic University of America Press, 2019.

Chrzczonowicz, Magdalena. "Zaufanie do Kościoła Spadło na teb na Szyję. Tak Złego Wyniku Nie Było od 27 Lat." Oko.Press, 2020. Accessed: January 19, 2021. https://oko.press/opinie-o-kosciele-katolickim-w-badaniu-cbos/

Cipressa, Salvatore. Sessualità, Differenza Sessuale, Generazione: a Cinquant'anni da Hummanae Vitae: Atti Del XXVII Congressonazionaledell'ATISM (Torino, 3-6 luglio 2018). Assi: CittadellaEditrice, 2019.

Curran, Charles. "Humanae Vitae: Fifty Years Later.” Theological Studies 79 (2018), 520-42.

Czuma, Beata. 2019. "Biskup Milewski o LGBT: 'Maryjo, zaradź rozprzestrzenianiu się chorej ideologii.” “Wiadomości wp.pl, 2018. Accessed: January 19, 2021. https://wiadomosci.wp.pl/biskup-milewski-o-lgbt-maryjo-zaradz-rozprzestrzenianiusie-chorej-ideologii-6410654505515137a

Delicata, Nadia. “Revisiting Humanae Vitae, Fifty Years Later.” In Strong Families - Strong Societies, edited by Elżbieta Osewska, 51-67. Kraków: The Pontifical University of John Paul II in Kraków Press, 2019.

Dobroczyński, Bartłomiej. “Żadnej rewolucji nie było.” Więź 51:7-8 (2008), 5-9.

Drelich, Stawomir. "Spóźniona rewolucja seksualna.” Liberté!, 2020. Accessed: January 20, 2021. https://liberte.pl/spoznionarewolucja-seksualna/

Duda, Sebastian. "Zgorszenie, wstyd i prawda: Krótki kurs teologii nagości." Więź 57:4 (2014), 184-94.

Dziaczkowska, Magdalena. "The Polish Case: Pedophilia, Polak-Katolik, and Theology of the Nation." Svensk Teologisk Kvartalskrift 96 (2020), 235-51.

Eberstadt, Mary, Hitchcock, James, and Fulwiler, Jennifer. On Humanae Vitae Pope Paul VI. San Francisco: Ignatius Press, 1994. Fairclough, Norman. Analysing Discourse. Textual Analysis for Social Research. London: Routledge, 2003.

Fatyga, Barbara. “Wciąż mało wiedzy.” Więź 51:7-8 (2008), 11-3.

Frankiewicz, Stefan, and Gawryś, Cezary. "Tadeusz w 'Więzi’, w Laskach i na wakacjach: Ze Stefanem Frankiewiczem rozmawia Cezary Gawryś.” Więź 55:4 (2012), 80-8.

Gawkowska, Agnieszka. “Jeszcze seksowniejsza rewolucja.” Więź 51:7-8 (2008),13-6.

Grimes, Katie M. "Theology of Whose Body? Sexual Complementarity, Intersex Conditions, and La Virgen de Guadelupe.” Journal of Feminist Studies in Religion 32 (2016), 75-93.

Grzybowski, Jerzy. "Ewolucja w rewolucji.” Więź 51:7-8 (2008), 19-22.

Guzik, Paulina. "An Unfinished Story of Conversion: Clerical Sexual Abuse in Poland." Church, Communication and Culture 5 (2020), 417-45.

Haffner, Debra H. and Ott, Kate M. A Time to Speak: Faith Communities and Sexuality Education. Norwalk: Religious Institute on Sexual Morality, Justice, and Healing, 2005.

Haynes, Jeffrey. "Right-Wing Populism and Religion in Europe and the USA.” Religions 11 (2020), 490. doi: 10.3390/ rel11100490.

Hinze, Bradford E. Practices of Dialogue in the Roman Catholic Church: Aims and Obstacles, Lessons and Laments. New YorkLondon: The Continuum International Publishing Group Inc, 2006.

Hittinger, Russell. “Natural Law as Law Reflections on the Occasion of Veritatis Splendor." American Journal of Jurisprudence 39 (1994), 1-32.

Hołuszko, Ewa. “Boga nie okłamywałam.” Więź 57:1 (2014), 67-75.

(Homosexualitatis Problema) Congregation for the Doctrine of the Faith. Homosexualitatis Problema. Letter to the Bishops of the Catholic Church on the Pastoral Care of Homosexual Persons. Rome: Libreria Editrice Vaticana, 1986.

Houghton, Marie, and Tasker, Fiona. "Exploring Lesbian and Bisexual Catholic Women's Narratives of Religious and Sexual Identity Formation and Integration." Journal of Homosexuality 68 (2019), 47-69. doi: 10.1080/00918369.2019.1624455.

(In-Flight Press Conference 2016) Francis [the pope]. "In-flight press conference of his Holiness Pope Francis FROM Azerbaijan to Rome.” Catholic News Agency, 2016. Accessed January 19, 2021. https://www.catholicnewsagency.com/news/full-textpope-francis-in-flight-press-conference-from-azerbaijan-24352

Izdebski, Zbigniew. "W Polsce wolniej.” Więź 51:7-8 (2008), 22-4.

Jabłońska, Katarzyna. "Pomiędzy.” Więź 50:10 (2007), 6-21. 
Jacobs, Brianne. “An Alternative to Gender Complementarity: The Body as Existential Category in the Catholic Tradition.” Theological Studies 80 (2019), 328-45. doi: 10.1177/0040563919836243

Jawor, Anna and Kurowicka, Anna. (eds.). Polska Transformacja Seksualna. Warszawa: Wydawnictwo Naukowe Scholar, 2016. John Paul II. Man and Woman He Created Them: A Theology of the Body. Boston, MA: Pauline Books \& Media, 2006.

Kapela, Jaś. “Biskup Jędraszewski, czyli ‘zaraza gorsza od cholery i bolszewizmu’ w Komisji Wspólnej Rządu i Episkopatu.” Krytyka Polityczna, 2021. Accessed January 19, 2021. https://krytykapolityczna.pl/kraj/biskup-jedraszewski-czyli-zarazagorsza-od-cholery-i-bolszewizmu-w-komisji-wspolnej-rzadu-i-episkopatu/

Keenan, James F. “Receiving Amoris Laetitia.” Theological Studies 78 (2017), 193-212.

Kelly, Conor M. "The Role of the Moral Theologian in the Church: A Proposal in Light of Amoris Laetitia." Theological Studies 77 (2016), 922-48.

Komonchak, Joseph A. "Humanae Vitae and Its Reception: Ecclesiological Reflections.” Theological Studies 28 (1978), $221-57$.

Kościańska, Agnieszka. "Humanae Vitae, Birth Control and the Forgotten History of the Catholic Church in Poland." In The Schism of '68: Catholicism, Contraception and Humanae Vitae in Europe, 1945-1975, edited by Alana Harris, 187-208. London: The Palgrave Macmillan, 2018.

Kuzmics, Helmut, Reicher, Dieter, and Hughes Jason. "State, Emotion, Authority, and National Habitus: State-Related Problems of Our Time and Methodological Discourses in Sociology and Historical Sociology." Historical Social Research 45 (2020), 7-41.

Leśniczak, Rafat. "Patriotyzm, homofobia i nietoleracja a wizerunek społeczności LGBT+ w polskich tygodnikach katolickich w kontekście marszów równości w 2019 r.” Zeszyty Prasoznawcze 63:3 (2020), 103-20.

Majewski, Józef. “Przerażającedane o księżach pedofilach.” Więź 52:5-6 (2009), 126.

Mandes, Stawomir. "Clerical Sexual Abuse in an Illiberal State: The Case of Poland." Journal of Church and State 62 (2020), 110-34.

Martin, James. Building a Bridge. How the Catholic Church and the LGBT Community Can Enter into a Relationship of Respect, Compassion, and Sensitivity, New York: HarperAudio, 2017.

(Mater et Magistra) John XXIII. Mater et Magistra: Encyclical on Christianity and Social Progress, New York: The America Press, 1961.

McCormick, Richard A. "Some Early Reactions to Veritatis Splendor." Theological Studies 55 (1994), 481-506.

McKee, Alan. "Resistance in Hopeless." Assimilating queer theory. “Social Semiotics 9 (1999), 235-49.

Melina Livio. Sharing in Christ's Virtues. For a Renewal of Moral Theology in Light of Veritatis Splendor. Washington D.C.: The Catholic University of America Press, 2001.

Mielczarek, Tomasz. “Współczesna polska prasa opinii.” Rocznik Historii Prasy Polskiej 16 (2013), 80-102.

Nosowski, Zbigniew. “All You Need is Sex?: Jak zmienia się wspótczesne rozumienie erotyki.” Więź 51:7-8 (2008), 72-83.

Nosowski, Zbigniew. “Historia Pisma.” Więź, 2019. Accessed: October 4, 2019. https://www.wiez.pl/czasopismo/;s, czasopismo,kat, 5

Odrowąż-Coates, Anna. "Gender Crisis in Poland, Catholic Ideology and the Media." Sociology Mind 5 (2015), 27-34.

Pasierb, Janusz. “Walczyć nie z kimś, ale o coś.” Więź 35 (1992), 48-9.

Pitoń, Angelika. “Abp Marek Jędraszewski nie odpuszcza: LGBT to trzecia ideologia zła, po nazizmie i stalinizmie.” Gazeta Wyborcza. Kraków, 2019. Accessed January 19, 2021. https://krakow.wyborcza.pl/krakow/7,44425,25302889,abp-marekjedraszewski-nie-odpuszcza-lgbt-to-trzecia-ideologia.html

Prusak, Jacek. "Ta rewolucja wymaga Ducha." Więź 51:7-8 (2008), 30-2.

Przeciszewski, Marcin. "Spada zaufanie do Kościoła.” OKO.press, 2020. Accessed: January 19, 2021. https://ekai.pl/spadazaufanie-do-kosciola/

Przygoda, Wiesław. "Paradygmaty metodologiczne we wspótczesności.” Teologia Praktyczna 10 (2009), 31-43.

Rezmer-Płotka, Kamila. “Activities of the Catholic Church in Poland Against Pedophilia in 2018." Polish Political Science Yearbook 48:2 (2019), 359-71.

Rudy, Kathy. Sex and the Church. Gender, Homosexuality and the Transformation of Christian Ethics. Boston: Beacon Press, 1997.

Rudy, Kathy. "Queer Theory and Feminism.” Women's Studies 29 (2000), 195-216.

Rudy, Kathy. "Radical Feminism, Lesbian Separatism, and Queer Theory.” Feminist Studies 27 (2001), 190-222.

Salzman, Todd A. and Lawler, Michael G. "Amoris Laetitia: Towards a Methodological and Antropological Integration of Catholic Social and Sexual Ethics.” Theological Studies 79 (2018), 634-52.

Sánchez, M. Soraya Garcia. “Michèle Roberts’s Protagonists: Catholicism and Sexuality.” Feminist Theology 17:2 (2009), 229-44.

Sands, Justin. “Introducing Cardinal Cardijn's See-Judge-Act as an Interdisciplinary Method to Move Theory into Practice." Religions 9:4 (2018), 129.

Smith, Janet E. Humanae Vitae: A Generation Later. Washington, D.C.: The Catholic University of America Press, 1991.

Smith, Janet E. (ed.). Why Humanae Vitae Was Right: A Reader. San Francisco: Ignatius Press, 1993.

Sosnowski, Jerzy. “Niegrzeczna Pobudka.” Więź 51:7-8 (2008), 34-7. 
Starego, Karolina. "Dyskurs.” In Dyskursywna konstrukcja podmiotu. Przyczynek do rekonstrukcji pedagogiki kultury, edited by Małgorzata Cackowska, Lucyna Kopciewicz, Mirosław Palaton, Piotr Stańczyk, Tomasz Szkudlarek, 26-36. Gdańsk: Wydawnictwo Uniwersytetu Gdańskiego, 2012.

Stuart, Elizabeth. Just Good Friends. Towards a Lesbian and Gay Theology of Relationships. New York: Mowbray, 1995.

Stuart, Elizabeth. Religion is a Queer Thing. A Guide to the Christian Faith for Lesbian, Gay, Bisexual and Transgendered People. London: Cassell, 1997.

Stuart, Elizabeth. Gay and Lesbian Theologies. Repetitions and Critical Difference. Aldershot, Hampshire, Burlington, VT: Ashgate, 2003.

SWPS University. “Otwarcie Wokót Seksualności. Cykl Spotkań z Młodzieżą - Projekt Nagrodzony w Ramach Konkursu na Najlepszą Inicjatywę Spoteczna 2020.” SWPS University, 2020. Accessed: January 20, 2021. https://www.swps.pl/ uczelnia/aktualnosci-uniwersytet-swps/22711-otwarcie-wokol-seksualnosci-cykl-spotkan-z-mlodzieza-projektnagrodzony-w-ramach-konkursu-na-najlepsza-inicjatywe-spoleczna-2020

(Catechism of the Catholic Church) John Paul II [approved and promulgated]. Catechism of the Catholic Church. Rome: Libreria Editrice Vaticana, 1992.

The Polish Bishops' Conference Episcopate. Stanowisko Konferencji Episkopatu Polski w Kwestii LGBT+. EKAl the Polish Catholic Information Agency, 2020. Accessed: January 19, 2021. https://ekai.pl/dokumenty/stanowisko-konferencji-episkopatupolski-w-kwestii-lgbt-dokument/

Thonheimer, Martin. “'Intrinsically Evil Acts' and the Moral Viewpoint: Clarifying a Central Teaching of Veritatis Splendor.” The Thomist: A speculative Quarterly Review 58 (1994), 1-39.

Tworzydło, Dariusz, Gawroński, Stawomir, and Zajic, Marek. "Catholic Church in Poland in the Face of Paedophilia. Analysis of Image Actions." European Journal of Science and Theology 16 (2020), 157-72.

(Veritatis splendor) John Paul II. Encyclical Veritatis splendor. Rome: Libreria Editrice Vaticana, 1993.

Węctawski, Tomasz. “Metodologia Teologii.” Poznańskie Studia Teologiczne 18 (2005), 7-24.

Wierzbicki, Alfred. “Odwaga myślenia według Wojtyły.” Więź 58:2 (2015), 126-32.

(Więź 2020) Więź. “Bp Jarecki: Dokument episkopatu o LGBT jest niepotrzebny. O Kai Godek: Ta pani nie zna doktryny.” Więź, 2020. Accessed: January 20, 2021. https://wiez.pl/2020/09/17/bp-jarecki-dokument-episkopatu-0-lgbt-jestniepotrzebny-o-kai-godek-ta-pani-nie-zna-doktryny/

“Więź zebrała na Patronite 200 tys. zł od czytelników.” Więź, 2020. Accessed: January 29, 2021, https://wiez.pl/2020/06/29/ wiez-zebrala-na-patronite-200-tys-zl-od-czytelnikow/

Wojtyta, Karol. The Jeweler's Shop. A Meditation on the Sacrament of Matrimony: Passing on Occasion into a Drama. San Francisco, CA: Ignatius Press, 1992.

Wojtyła, Karol. Love and Responsibility. Boston, MA: Books \& Media, 2013. 


\section{Appendix}

1. List of Więź issues from 2007 to 2020: 2007: 10 issues (1, 2, 3, 4, 5, 6, 7, 8-9, 10, 11-12), 2008: 8 issues (1, 2-3, 4-5, 6, 7-8, 9, 10, 11-12), 2009: 8 issues (1-2, 3, 4, 5-6, 7, 8-9, 10, 11-12), 2010: 8 issues (1, 2-3, 4, $5-6,7,8-9,10,11-12), 2011: 8$ issues $(1,2-3,4,5-6,7,8-9,10,11-12), 2012: 8$ issues $(1,2-3,4,5-6,7$, 8-9, 10, 11-12), 2013: 4 issues (1, 2, 3, 4), 2014: 4 issues (1, 2, 3, 4), 2015: 4 issues (1, 2, 3, 4), 2016: 4 issues $(1,2,3,4), 2017: 4$ issues $(1,2,3,4), 2018: 4$ issues $(1,2,3,4), 2019: 4$ issues $(1,2,3,4)$, and 2020: 4 issues $(1,2,3,4)$.

2. List of Więź issues with at least one sexuality- or gender-related theme: 2007: 5, 7, 10, 11-12; 2008: 1, 4-5,6, 7-8, 9; 2009: 1-2, 5-6, 11-12, 8-9; 2010: 2-3; 2011: 8-9; 2012: 7, 8-9; 2013: 2; 2014: 1, 4; 2015: 1, 2; 2016: 2, 3, 4; 2017: 2; 2018: 2, 3; 2019: 1, 4; 2020: 3, 4.

3. The Więź issues with special sexuality- or gender-related themes:

Rodzice i homoseksualizm [Parents and Homosexuality]: (2007) no. 10.

Rewolucja seksualna po czterdziestce [A Sexual Revolution in One's Forties]: (2008) no. 7-8.

Kościót jest kobieta [The Church is a Women]: (2009) no. 1-2. It should be remembered that narration on woman and feminist theology appear frequently in Więź: (2007) no. 7, 11-12; (2008) no. 1, 4-5, 7-8, 9; (2009) no. 1-2, 5-6; (2010) no. 2-3; (2014) no. 1; (2020) no. 4.

Życie w tańcu [Life in dance] (2012) no. 8-9. An attempt to display the body experience in the context of motion, movement, art, creativity, self-expression, sexuality, and gender.

Gendery dobre i zte [Good and Bad Genders]: (2014) no. 1. A heterogeneous debate on the definition of "gender" and its social and religious implications.

Rozbieranie nagości [Undressing Nudity] (2014) no. 4. Search for a better understanding of the body and nudity in cultural and theological context.

Kościót rozliczany i przejrzysty [The Accountable and Transparent Church]: (2019) no. 1. A strong postulate for greater empathy toward victims of pedophilia and for the accountability of priests and bishops guilty of pedophilia and its cover-up in Poland.

Jak się różnić $i$ żyć wspólnie; oraz Inny musi znaczyć zły? [How to Differ and Live Together; and: Must the Other Mean Evil?]: (2020) no. 4. An issue dedicated to social differences. 